\title{
The Implementation of Speaking Fluency in Communicative Language Teaching: An Observation of Adopting the 4/3/2 Activity in High Schools in China
}

\author{
Yingjie I. J. Yang \\ University of Southern Queensland, Australia \\ E-mail: u1040470@umail.usq.edu.au
}

Received: February 6, 2014 Accepted: February 16, 2014 Published: February 16, 2014

doi:10.5296/ijele.v2i1.5136 URL: http://dx.doi.org/10.5296/ijele.v2i1.5136

\begin{abstract}
Communicative language teaching is a very popular approach in the EFL class, which is also advocated in many Asian countries. Is it effectively applied in the Chinese EFL classes so far? The current situation of the communicative language teaching in China was not persistently implemented due to many constraints. However, this article aims to indentify a gap between the principle of CLT and its practice in the EFL class. The research in the article is associated with the EFL learners' speaking fluency and the context of communicative language teaching. Thus, an observation of adopting the 4/3/2 activity in the high schools in China is to point out the lack of speaking fluency development is neither beneficial nor sufficient for CLT; to find out the major achievements of the speaking fluency practice in long term; and to justify the speaking fluency is a trainable skill in the context of CLT. Nonetheless, the obtained results indicate both the EFL teachers and learners are taken into account for the effectiveness and achievement of fluency development in speaking. Findings in data and factor analysis suggest that the EFL teachers should draw attention on relevant pedagogical implication and the EFL learners are strongly encouraged to put efforts on learning strategies. Such considerations are necessary to be involved in the EFL teaching and learning. Therefore, the conclusion of study is, within a collaborative learning environment, the implementation of the speaking fluency is took place dramatically to enhance the effectivenesses of CLT and that indeed needs a long term effort, patience and monitoring in the EFL class.
\end{abstract}

Keywords: speaking fluency, communicative language teaching - CLT, fluency development, the $4 / 3 / 2$ activity, communicative competence, motivation, learning strategies, EFL teaching and learning 


\section{Introduction}

Communicative language teaching is dominated in many ESL/EFL classes in the world today, which was initially proposed in the ESL class in the 1970s (Habermas, 1970; Hymes, 1971; Savignon, 1972). Richards (2006) amplified that CLT created a great deal of enthusiasm and excitement in language education, because the purpose of language teaching is to develop the learners' communicative competence in authentic contexts and CLT also acknowledges the interdependence between language and communication (Larsen-Freeman, 2000). It therefore advocates the teachers to consider: adjusting the traditional curriculum and designing relevant activities, choosing interesting topics to motivate their students, and creating opportunities for interaction in class, which is an emphasis on the delivery of meaning rather than the linguistic feature or grammar structure. This causes many traditional teaching methods are replaced, for instance, the grammar translation method was eventually changed into the approach of CLT in many language classes.

However, researches indicated the efficacy and effectiveness of CLT in EFL class in China is not the same by contrasting with the ESL class (Anderson, 1993; Harvey, 1985; Liao, 2004; Penner, 1995; Sampson, 1984; Yu, 2001), since the CLT was not sufficiently introduced in the Chinese EFL context. For other EFL countries, CLT also faces the resistance in India (Deepti, 2004) and South Korea (Li, 1998). This implies there are some differences for implementing CLT between the EFL and ESL contexts. Stern (1992) argued such differences can be located in the language environment and learner's motivation, more specifically, Sampson (1984) had demonstrated these differences in terms of the political influences, the cultural diversities and the educational values. Wu (2008) further found there are several misunderstandings for the CLT in China, so this article attempts to indentify the gap between the principle of the CLT and its practice in the EFL class. The related research is associated with the EFL learners' speaking fluency and the CLT context in China.

The approach of CLT is a broad concept to develop the communicative competence including: a) linguistic/grammatical competence: the use of vocabulary and grammatical rules (Canale \& Swain 1980), b) sociolinguistic/pragmatic competence: the appropriateness of expression in communication (Canale \& Swain 1980), c) discourse competence: cohesion and coherence (Canale, 1983), d) strategic competence: the application of communication strategies (Canale \& Swain, 1980; Hedge, 2000; Richards \& Rogers, 1986) and e) fluency (Brown, 2007; Hedge, 2000). However, this observation of adopting the 4/3/2 activity (Maurice, 1983) relies on the development of speaking fluency: to find out the major achievements of the speaking fluency with practice; to justify the lack of speaking fluency is not sufficient for speaking competence, and to conclude that speaking fluency is a trainable skill through the context of CLT.

\section{Literature Review}

Speaking fluency is an important dimension of communicative language teaching, but there are some constraints and misunderstandings of CLT that could neglect the implementation of it in the EFL class. In this case, it is necessary to identify why and how to understand the features of CLT first and then to ensure the correct rationale of applying CLT. In addition, the importance of speaking fluency development is also reviewed and discussed. 


\subsection{The Overview of CLT}

Canale and Swain (1980) suggested the linguistic competence and sociolinguistic competence should be integrated in syllabus design for language teaching. There is an interaction between the grammatical and pragmatic competences in CLT, because competence is regarded as an overall knowledge and ability in language learning (Hymes, 1972). This is a development of the concept of communicative competence, which derived from Chomsky's (1965) distinctive explanation of competence and performance. The term competence also refers to the listening, speaking, reading and writing four skills as a whole in language learning, which processes the context, comprehensive input and productive output.

However, Widdowson (1978) pointed out the differences between the use of language as a linguistics system - cohesion and with communicative purpose - coherence. He claimed that cohesion applies the linguistic knowledge together with discourse to link the contextual situations, so language teaching is taking place with such meaningful interaction. Moreover, learning strategies (Oxford, 1997) consists of cooperative learning, collaborative learning and interaction, three communicative strands which can help the language learners to comprehend different activities and to solve problems for the CLT tasks in the EFL classroom. In addition, Hedge (2000) added fluency competence into CLT, because speakers are strongly required to articulate smoothly, coherently and naturally without excessive repetitions or pauses.

CLT has some principles and the first one is the function of language teaching and learning is to assist the learners to understand the purpose of learning and to enhance the communicative competence in communication (Richards \& Rogers, 2002), which is spelled out that language as a social tool in society. Secondly, the EFL teachers have responsibilities to conduct their EFL lessons towards to the authentic contexts, since Clarke and Silberstein (1997) argued the communicative tasks in class need to be close to the real conversations as fully as possible. Therefore, the activities and materials should be concentrated on the meaning rather than the other factors. The third CLT principle is that the teachers do not always correct errors for their learners, which implies the fluency strand is concerned in communicative language teaching, hence Richards (2006) argued one of the goals of CLT is to develop fluency in language use. To sum up, these are the key principles of the CLT approach.

\subsection{The Constraints of CLT}

There are many constraints on the implementation of CLT, but the misunderstanding of CLT is a primary constraint according to the previous researches (Guo, 2004; Wu, 2008). First, the misunderstanding of CLT is an exclusive focus on meaning. This is a radical view with theory support from Prabhu (1987) who strongly argued grammar is too complicated to be taught in class and Krashen (1982) who claimed grammar only can be acquired unconsciously. Thus, some Chinese EFL teachers started to accept the approach of CLT and they believe attention is paid on the meaning rather than the form. Wu (2008) pointed out the current situation of CLT in the EFL classes in China: many EFL teachers are not fully ready to adapt CLT, but combine with grammar translation method to balance meaning and form. However, grammar translation method is with no rationale and theory support (Richards \& Rogers, 2002). 
Therefore, the issue of whether focusing on meaning or form, similarly, fluency or accuracy should be seriously treated in class. Nation's (2007) four strands in communicative language teaching: a) language learning through listening and reading is classified into the strand of meaning-focused input; b) speaking and writing which refers to meaning-focused output; c) form-focused instruction is focusing on learning language features; and d) the fourth strand is the fluency development. In addition, Guo (2006) supported that the EFL teachers in China emphasize accuracy in writing and fluency in speaking, which is treated as equal importance in both form and meaning.

Secondly, the misunderstanding of CLT is that it should not offer feedback when learners are making a mistake, which means there is no explicit on learner's errors. Wu (2008) found the relevant explanation to this misunderstanding as many EFL teachers in China believe errors are the phenomena of making learning progress and they will be eliminated and instead of the accurate forms with opportunities to practice. Grammar instruction (Fotos, 2001) is beneficial for the EFL learners to be aware of the learning progress. To correct the target errors in the conversation will disrupt the delivery of meaning and thus these errors will not be pointed out immediately by the EFL teachers. Guo (2006) further suggested that the grammar errors can be tolerant to some extent. However, errors are possible to be fossilized, which is a risk based on Candlin's (1988) theory: the error is possible to be the incorrect permanent form in future language use. So, this is definitely a threat in language learning.

Ellis (1984) pointed out the use of L1 in L2 class will deprive the learners of comprehensive input. The reason is that the learners have to face the target language in order to become a successful learner of L2. Due to the environment of limited time and the lack of L2 use, the EFL teachers cherish the time in class and try to catch every opportunity for their learners to practice L2 as much as possible. At the same time, some EFL teachers accept the CLT, who deeply trust the "English Only" policy (Auerbach, 1993), so it is not necessary to force their students to use L1 processing the target language. Different language teaching methods, obviously, influenced by their principles which directly determine the instructions in the EFL class. Auerbach (1993) further pointed out the English only policy is more political influence than pedagogical instruction. This is the third constraint on the CLT approach in the Chinese EFL classes.

On the other hand, there is no sufficient evidence to avoid using L1 in the EFL classroom and banning L1 is not reasonable. Ellis (2008) assumed that L1 can be a valuable tool of cultural knowledge to prepare for L2 input. Anton and DiCamilla (1998) explained the socio-cultural framework and claimed the use of L1 is a way of promoting the learners' cognitive process to understand and overcome communicative tasks. Other researches (Bouangeune, 2009; Nation, 1997b; Tang, 2002) proceeded that there are many benefits for using L1 in language class. The role of L1 is a very effective tool to support the teaching and learning in terms of some pedagogical advantages: saving the time, providing clear instruction and directing the goal according to Turnbull (2001). To conclude, it is necessary to re-evaluate the role of the first language in the EFL classroom in order to best fit the teaching situation and the EFL teachers should be careful when participants using their native language since most EFL learners in China share the common language - Mandarin. 
There are some other constraints, for example, the constraint on textbook, authentic language environment, learning styles, education policy and so on. Textbook easily becomes a restrict factor when implementing communicative task, because interaction among the EFL learners in conversation is not likely to be happened if strictly following a textbook. The teachers need to choose relevant materials besides the textbooks and to organise interesting activities in the CLT class (Brown \& Yule, 1983). One intrinsic difference between ESL and EFL is that there is little native language speaking environment outside the EFL class. Thus, many students in the EFL class consider the learning is just a game which is hardly to apply the communicative competence in real life. Richards (2008) argued that learning is not confined only the class, but with information technique, internet, computer, and video facilities, that indeed maintain the learning in an authentic context. Nonetheless, Hird (1995) found the students have to deal with a lot of paper work, because both the curriculum and assessment in the Chinese national educational system is exam-driven. Jin (2006) pointed out the learning style still relies on a lot of memorization for most EFL students in China to learn vocabulary through memorizing. In addition, situational factors (Yu, 2001) such as the class size, management and instruction, learners' proficiency level and willingness of participation will also impact the CLT in class.

\subsection{The Importance of Speaking Fluency in CLT}

Brumfit (1984) considered fluency as natural language use like the native speakers. That the ability one speaks fluently can sustain the speaker to produce continuous speech and meaning without comprehension difficulties for the listener. Richards et al. (1985) argued the strand of fluency is a measurement of one's communicative proficiency level. As a result, it is obvious that the speaking fluency is an important component of the communication competence. Hedge (2000) eventually put the fluency development into the criteria list of communicative competence for being a successful English speaker.

Unlike the traditional grammar translation method, which is a structure-based teaching model pays attention on grammar structure rather than developing their listening and speaking skills. Instead, CLT requires the teachers to seek and present tasks for developing communicative skills. Richards (2006) maintained that the speaking fluency is developed by many variables: the interaction in problem solving tasks, the negotiation of meaning in pair work and the use of communication strategies. Regardless, Ellis and Sinclair (1989) advised the language learners are supposed not to make pauses, instead speaking meaningfully and naturally, with no excessive repetition. Whereas teacher's role is to correct the students' misunderstandings and guide them avoiding communication breakdowns (Richards, 2006).

Based on Fillmore's (1979) definition of speaking fluency: a) the ability to talk at length with few pauses; b) be able to produce sentences coherently, reasoned and semantically; c) have appropriate expressions in a wide range of contexts; d) language use should be creative and imaginative. Hedge (2000) further stated that speaking fluency is in line with: 1) the coherent response within the turns of communication; 2) appropriate use of linking different devices; 3 ) intelligible pronunciation and proper intonation. In addition, the reason why Hedge (2000) insisted on the importance of fluency development is that focusing on the speaking fluency creates a comfortable feeling and cultivates learners' self-confidence through CLT. 


\subsection{Related Empirical Studies}

Nation (1989) applied the 4/3/2 activity (Maurice, 1983) for six adult learners to observe the improvements in speaking fluency, grammar accuracy and control of the content after a short period of time. In his study, Nation (1989) found that the practice of the speaking fluency is not conflict with the form-focused instruction instead strongly enhances its grammar accuracy. In the same manner, Arevart and Nation's (1991) fluency improvement in learning a second language with the 4/3/2 activity illustrated the students' performance was dramatically high. Their research analyzed the amount of words articulated per minute and the average pauses between the different syllables when speaking and these two variables were improved. Nation (1997a) further pointed out that developing fluency in language use should share one quarter of class time and claimed the fluency activity aims to develop the listening speaking reading and writing skills in general on account of these four skills are internal related and affected in the communicative language teaching.

Along the same line, Kormos and Denes (2004) had attempted to explore the measures and perceptions of fluency for the second language learners. They found speech rate, mean length of runs, phonation-time ratio, pace which refers to the number of stressed words pronounced per minute, are the predictors of speaking fluency. Kormos and Denes (2004) did not find the numbers of filled and unfilled pauses that influence the speaking fluency, but they concluded the concept of speaking fluency is best described as smoothness, speed, pace and accurate production of a language. Under these conditions, the accuracy is an essential component in speaking fluency since they believe accuracy and speaking speed are positively interacted. On the other hand, de Jong and Perfetti (2011) also applied the 4/3/2 activity in a different way to compare with Arevart and Nation's (1991) observation above. They set up two groups: one repeated the same topic and the other changed into different topics in the three sessions in the 4/3/2 activity. Results indicated that the speaking fluency is improved by both groups, but the participants in the repeated group repeated more words, but not closely related to the topic of conversation. Therefore, de Jong and Perfetti (2011) argued that the 4/3/2 activity not only develops speaking fluency which transfers to new topics after training, but also changes the processing of language knowledge due to proceduralization which enables fluent production pausing less and filling more in the speech.

\section{Significance of Study}

The former discussion clearly maintains that speaking fluency is an important communicative competence. As a mater of fact, this study attempts to explore that how the speaking fluency is improved through a long term observation. It is also clear that the misunderstandings of CLT lead to a less effective outcome, so the study aims to stipulate the implementation of speaking fluency with detailed guidelines and instructions of the 4/3/2 activity for the EFL teachers and learners. The learners are arranged to be evaluated the speaking competence in terms of before and after the observation by professional examiners. On the other hand, the relationship between the learners' preference of practicing speaking fluency and the teachers' willingness of implementing the speaking fluency is tested and the issue of gender variable is also considered by contrasting different groups in this study. 
To sum up, the significance of study lies in the fact that it concerns a wide range of issues and problems mentioned above. The engagement in this article will cover, analyze and solve the relevant speaking fluency problems that are totally or partially neglected in communicative language teaching in the EFL class in China. The stated questions are listed below:

- Question 1: Is the speaking fluency well developed in the EFL class in China?

- Question 2: Is speaking fluently a trainable skill through CLT in the EFL class?

- Question 3: What are the major achievements to implement the $4 / 3 / 2$ activity?

\section{Research Methodology}

\subsection{Participants}

The participants in this research included 302 EFL students and 35 EFL teachers from several different senior high schools in the mainland of China. The survey sample consisted of 152 male and 150 female students from sixteen to eighteen years old who were randomly selected by their teachers. Their grammar background is good, but the speaking proficiency is various: very few students can speak fluently with the practiced content in class; most of them speak with pauses and hesitations who are struggling but self-motivated; nearly one quarter of the students articulate slowly and are unable to make long sentences, because they spend time on recall words by memory and attempting to translate grammars from L1 to L2; and a few of them only can produce single words and short expressions. The average rate is approximately on an intermediate speaking level. On the other hand, the 17 male and 18 female teachers ranged from 29 to 43 years old were recognized as the local EFL teachers who were trained domestically. On the basis of the reliability and validity in this research, there were neither overseas nor native English teachers who were involved in the research. The sample teachers were chosen by at least five years teaching experiences in the EFL filed in China. With regard to the demography background, both male and female are almost equal in the teacher's and student's groups.

Table 1. Descriptive statistics of participates' demography information

\begin{tabular}{c|c|c}
\hline Student & Numbers & Percentage \\
\hline Male & 152 & $50.33 \%$ \\
\hline Female & 150 & $49.67 \%$ \\
\hline Total & 302 & $100.00 \%$ \\
\hline
\end{tabular}

\begin{tabular}{c|c|c}
\hline Teacher & Numbers & Percentage \\
\hline Male & 17 & $48.57 \%$ \\
\hline Female & 18 & $51.43 \%$ \\
\hline Total & 35 & $100.00 \%$ \\
\hline
\end{tabular}

\subsection{Instruments}

The research was conducted with the 4/3/2 activity, in which the EFL students were asked to participate every week. The observation was lasting three months with a 14 weeks period; therefore, the 14 topics (from topic 2 to 15) in table 5 were used. The first topic in table 5 was a demonstration and the last one was used for final evaluation. Both teachers and students have enough time to prepare the task each week. Moreover, all the EFL teachers and students in this observation were required to understand the conditions and procedures to implement the $4 / 3 / 2$ activity. This is the technique of improving speaking fluency. 
There is a questionnaire in appendix for all the participants to answer. All six questions were compulsory in order to collect enough information for data analysis. Question 1 is about the demography survey including the gender and role. Both question 2 and 3 are relevant to the importance and necessity of speaking fluency for both students and teachers. There is a rating from '1-strongly disagree' to '5-strongly agree' for participants to comment on the amount of speaking fluency practice and the preference/willingness of developing speaking fluency in question 4 and 5. Then, question 6 is the about the preference of speaking topics selected by these students. However, the last question is to evaluate the students' speaking competence before and after this observation by different examiners. The achievement and improvement of this observation can be assessed by the two different scores through this question.

\subsection{Procedure}

Step 1: The preparation of running the $4 / 3 / 2$ activity

The researcher should instruct all 35 EFL teachers how to implement the speaking fluency through the 4/3/2 activity, because some of them may not be familiar with such technique in China. Some of these EFL teachers may know and had already applied this activity in their classes, but it is still necessary to run an in-service lesson for all participating teachers. The teachers are strongly recommended to write down a checklist about the conditions of running the 4/3/2 activity: a) learners must be familiar with and totally understand the language items and content, no new language items and content; b) comprising meaning-focused activities that means it is possible for the learners to make some mistakes; c) the class should be with an even number in a face-to-face sittings, at least six students but no maximum; d) three rounds for a speaker to talk repetitively at a decreased time from 4 minutes at 1 st round, to 3 minutes in middle and 2 minutes for the 3rd round; f) require a time keeper to count minutes.

Step 2: To monitor the implementation of the $4 / 3 / 2$ activity

This speaking fluency development observation should be under the supervision with a clear guide. Nation (1989) summarized it into the following three features: 1) the speakers repeats the same talk, but with a reduced duration of time through pair work: one is listener and the other is speaker; 2) quickly switching the role in each round once finished and there is no interruption during the whole task, so listener is not allowed to ask question to the speaker; 3) the speaker always has a different audience in each round and the attention for the speaker is to focus on meaning and communicative message. Based on these conditions and features, all activities will be kept in the same track, as a consequence the results from the observation will be more reliable and valid.

Step 3: The processing of the survey and questionnaire

The next step is to process the survey and collect data by different questions. The researcher ought to instruct the participants to answer every question in the survey as fully as possible. Besides this survey, interview with the students is also an effective way to collect information, for example, to know what they like and dislike with reasons, to explore what they did well and poor through the observation, and to provide necessary support if participants need. The researcher should collect data to analyze them and seek answers for the stated questions. 


\subsection{Data Collection and Analysis}

Table 2. Feedback on the importance and necessity of the speaking fluency in communicative language teaching and learning for all participants

\begin{tabular}{l|l|l|l|l|l}
\hline Criteria & $\begin{array}{l}\text { Very } \\
\text { important }\end{array}$ & Important & $\begin{array}{l}\text { Important to } \\
\text { some degrees }\end{array}$ & $\begin{array}{l}\text { Not sure, } \\
\text { uncertain }\end{array}$ & $\begin{array}{l}\text { Not important at } \\
\text { all }\end{array}$ \\
\hline Percentage & $33.53 \%$ & $54.30 \%$ & $10.98 \%$ & $1.19 \%$ & $0 \%$ \\
\hline Criteria & $\begin{array}{l}\text { Essentially } \\
\text { necessary }\end{array}$ & Necessary & $\begin{array}{l}\text { Necessary to } \\
\text { some extend }\end{array}$ & $\begin{array}{l}\text { Not sure, } \\
\text { uncertain }\end{array}$ & $\begin{array}{l}\text { Not necessary at } \\
\text { all }\end{array}$ \\
\hline Percentage & $29.08 \%$ & $56.38 \%$ & $13.65 \%$ & $0.89 \%$ & $0 \%$ \\
\hline
\end{tabular}

It is obvious that the majority of teachers and students consider speaking fluency is important and necessary in communicative EFL class in China. This is a fundamental finding to support the implementation of speaking fluency immediately.

Rossiter et al. (2010) found speaking fluency is a neglected component in the communicative ESL classroom. So that, the fourth question from the survey in appendix refers, whether the practice and development of speaking fluency in the EFL class is enough to maintain the communicative language usage or not, is a way to explore there is a lack of speaking fluency practice in the EFL class in China..

Table 3. The results on the lack of practice and the preference/willingness of practice and teaching speaking fluency in the EFL class

\begin{tabular}{|c|c|c|c|c|c|c|}
\hline \multirow{2}{*}{ Students } & \multicolumn{2}{|c|}{ Lack of practice } & \multicolumn{2}{|c|}{ Preference of practicing } & \multirow[b]{2}{*}{ T-calculate } & \multirow[b]{2}{*}{ Sig. (2-tailed) } \\
\hline & Mean & SD & Mean & SD & & \\
\hline$\hat{\circ} \mathrm{M}(\mathrm{n}=152)$ & 4.35 & 0.93 & 4.29 & 0.87 & 1.3553 & 0.18 \\
\hline 우 $\mathrm{F}(\mathrm{n}=150)$ & 4.37 & 0.75 & 4.46 & 0.63 & -1.1254 & 0.26 \\
\hline \multicolumn{7}{|c|}{$* *$ Significant at the 0.01 level two tailed $\mathrm{t}$-test } \\
\hline \multirow{2}{*}{ Teacher } & \multicolumn{2}{|c|}{ Lack of practice } & \multicolumn{2}{|c|}{ Willingness of teaching } & & \\
\hline & Mean & SD & Mean & SD & T-calculate & Sig. (2-tailed) \\
\hline$\hat{O} M(n=17)$ & 4.52 & 0.52 & 4.61 & 0.84 & -0.3756 & 0.71 \\
\hline 우 $\mathrm{F}(\mathrm{n}=18)$ & 4.47 & 0.47 & 4.65 & 0.71 & -0.8968 & 0.38 \\
\hline
\end{tabular}

In spite of the lack of speaking fluency development, both these teachers and students have a strong desire to enhance the speaking fluency as a speaking competence in question 5 with the results in table 3 , too.

From a quantitative point of view, the t-test is applied to investigate the relationship between the lack of practice and preference of learning and willingness of teaching in two groups. In the students' group, result indicate that both male and female students think there is a lack of speaking fluency development, but they prefer to practice it. So do the male and female teachers' group as all the teachers would like to enhance the teaching of speaking fluency based on the lack of speaking fluency development. 
Furthermore, it is worth to investigate whether there is relation or difference between gender and role about the students' preference of practicing the speaking fluency and the teachers' willingness of implementing it. Four sets of data are tested through the t-test in table 4 below.

Table 4. The t-test of the students' preference of practicing speaking fluency and the teachers' willingness of implementing speaking fluency with four different demographic pairs:

\begin{tabular}{c|c|c|c|c|c|c|c|c}
\hline & \multicolumn{3}{|c|}{$\begin{array}{c}\text { The students' preference } \\
\text { of practicing speaking } \\
\text { fluency }\end{array}$} & \multicolumn{2}{c|}{$\begin{array}{c}\text { The teachers' willingness } \\
\text { of implementing speaking } \\
\text { fluency. }\end{array}$} & & \\
\cline { 2 - 9 } & Gender & Mean & SD & Gender & Mean & SD & T-calculate & Sig. (2-tailed) \\
\hline 1 & $\mathrm{M}(\mathrm{n}=152)$ & 4.29 & 0.87 & $\mathrm{M}(\mathrm{n}=17)$ & 4.61 & 0.84 & -1.4842 & 0.14 \\
\hline 2 & $\mathrm{~F}(\mathrm{n}=150)$ & 4.46 & 0.63 & $\mathrm{M}(\mathrm{n}=17)$ & 4.61 & 0.84 & -0.7139 & 0.48 \\
\hline 3 & $\mathrm{M}(\mathrm{n}=152)$ & 4.29 & 0.87 & $\mathrm{~F}(\mathrm{n}=18)$ & 4.65 & 0.71 & -1.9822 & $0.05^{*}$ \\
\hline 4 & $\mathrm{~F}(\mathrm{n}=150)$ & 4.46 & 0.63 & $\mathrm{~F}(\mathrm{n}=18)$ & 4.65 & 0.71 & -1.0852 & 0.28 \\
\hline \multicolumn{8}{c|}{$* *$ Significant at the 0.01 level two tailed t-test } & \\
\hline
\end{tabular}

Four pair data proved that either male or female students' preference of practicing speaking fluency are internally related to either male or female teachers' willing implementing decision of speaking fluency. Through, the male students' preference and female teachers' willingness is not very strong if at $\mathrm{p}<0.05$, (Sig. $=0.05)$. On a whole, there is a close matching between two variables: students' preference of practicing and teachers' willingness of implementing speaking fluency. This relationship does not affect by gender. The result perfectly provides a good teaching and learning environment for implementing the $4 / 3 / 2$ activity.

Table 5. Students' selection of the favorite speaking topics that they would like to practice

\begin{tabular}{|l|l|l|}
\hline \multicolumn{1}{|c|}{ Topic } & \multicolumn{2}{c|}{ Preference } \\
\hline & Male & Female \\
\hline To do a self-introduction & $85.10 \%$ & $81.13 \%$ \\
\hline Introduce and describe your family & $80.46 \%$ & $78.81 \%$ \\
\hline Share your school life to your classmates & $79.47 \%$ & $85.43 \%$ \\
\hline Weather in your city & $69.87 \%$. & $67.22 \%$ \\
\hline Transportation development & $64.24 \%$ & $61.26 \%$ \\
\hline Sports and competition & $91.72 \% * *$ & $37.42 \% *$ \\
\hline Entertainment and hobby & $87.09 \%$ & $83.77 \%$ \\
\hline Discuss shopping experiences & $41.72 \% *$ & $93.38 \% * *$ \\
\hline How to find a job & $77.15 \%$ & $79.80 \%$ \\
\hline Ask the way and giving direction & $66.23 \%$ & $59.27 \%$ \\
\hline Talk about the daily food & $76.82 \%$ & $82.12 \%$ \\
\hline Explore how to keep healthy & $73.51 \%$ & $80.13 \%$ \\
\hline Dreams in your life & $87.09 \%$ & $85.76 \%$ \\
\hline Travel to a place & $83.11 \%$ & $90.73 \%$ \\
\hline Your future plan and plan your future & $89.40 \%$ & $87.75 \%$ \\
\hline Introduce one of your best friends & $80.46 \%$ & $76.16 \%$ \\
\hline
\end{tabular}


The data illustrate that students have chosen the most favorable conversations and in general, they treat these topics at a high preference level. Three topics are with lowest ratings 'weather in your city', 'transportation development', and 'ask the way and giving direction'. On the contrary, 'to do a self introduction' and 'your future plan and plan your future' are two top choices by both male and female. In particular, 'sports and competition' is very popular by male at $91.72 \%$, but with a lowest selection $37.42 \%$ by female, whereas 'discuss shopping experiences' is rated highest $93.38 \%$ by the girls and only $41.72 \%$ by the boys. It could be understood by the common sense that girls like shopping while boys enjoy sports.

Table 6. Improvements of speaking fluency with specific criteria

\begin{tabular}{|l|c|c|}
\hline \multicolumn{1}{|c|}{ Criteria } & Before & After \\
\hline $\begin{array}{l}\text { (1) Linguistics knowledge i.e. grammar, vocabulary and etc, is } \\
\text { expand and becomes more accurate }\end{array}$ & 3.1 & 3.5 \\
\hline (2) Pragmatic and logic is in structured sentences and sequences & 2.8 & 3.3 \\
\hline (3) Expression is coherent with less pause while speaking & 2.9 & 3.4 \\
\hline (4) Speaking is fluent and the word articulation is fast & 2.7 & 3.3 \\
\hline $\begin{array}{l}\text { (5) Be able to use conversational strategies in comprehension to } \\
\text { maintain communication effectively }\end{array}$ & 3.0 & 3.2 \\
\hline (6) Be confident in speaking with others & 3.1 & 3.6 \\
\hline
\end{tabular}

Table 7. Overall achievement in practicing the speaking fluency through the 4/3/2 activity

\begin{tabular}{c|c|c|c|c|c}
\hline $\begin{array}{c}\text { Overall speaking proficiency } \\
\text { before the observation }\end{array}$ & $\begin{array}{c}\text { Overall speaking proficiency } \\
\text { after this observation }\end{array}$ & \multicolumn{2}{c}{ Paired t-test } \\
\hline Mean $(\mathrm{n}=303)$ & $\mathrm{SD}(\mathrm{n}=303)$ & Mean $(\mathrm{n}=303)$ & $\mathrm{SD}(\mathrm{n}=303)$ & T-calculate & Sig. 2 tailed \\
\hline 2.95 & 0.78 & 3.40 & 0.67 & -7.6053 & $0.00 * *$ \\
\hline \multicolumn{7}{r}{$* *$ Significant at the 0.01 level two tailed t-test } \\
\hline
\end{tabular}

From 2.95 to 3.40 , that is the improvement with 3 months of practicing. The t-test is applied again: the $\mathrm{T}$ value is calculated as -7.6053 with Sig. (2 tailed) of $0.00^{* *}$, therefore the t-test indicated that there is significant difference between pre and post the observation. Both the first and final speaking performance was evaluated and examined by different examiners, the professional EFL teachers and instructors, so the conclusion is the speaking competence is improved after implementing the speaking fluency through the $4 / 3 / 2$ activity in a long term.

\section{Findings and Discussion}

This study was carried out to scrutinize the issue of the implementation of speaking fluency through communicative language teaching in the EFL class. First of all, the importance and necessity of speaking fluency to develop speaking competence were reviewed theoretically by literature, but also examined by the questionnaire practically in the survey. The findings in question 2 and 3 consequently demonstrated that both the teachers and students had noticed the importance and necessities of speaking fluency in communicative language teaching. This is a fundamental starting point of doing this research and attempting to promote the speaking fluency in the EFL class. 
Secondly, the statistical data of question 4 reported in Table 3 clearly presented a situation that speaking fluency was ignored in their classes. This is because of the traditional teaching pattern and idea that still influenced the quality of communicative language teaching. It also concerned with the constraints and misunderstandings of communicative language teaching discussed aforementioned. To say the least, the researcher was told that many EFL teachers put 'form' to a higher status than 'meaning' due to the exam-driven curriculum through the interviews. This finding is consistent and corroborated with the situation (Rossiter et al., 2010) that oral fluency is neglected in the communicative ESL class. Thus, attention should be paid on this issue in the other levels of EFL institutions rather than the high schools.

However, both the EFL students and teachers are very keen to improve the speaking fluency according to question 5 in the survey. The finding suggested that fluency development should be allocated into the course immediately. Nation (1997a) advised the right amount of fluency development should be one quarter of the class time. This can admittedly help the learners to practice what they have already known and to use these familiar language items and contents at best. Rossiter et al. (2010) pointed out the free production activities in textbooks are not sufficient to enhance the speaking fluency in ESL class. The 4/3/2 activity with guidelines including the conditions and features are instructing the EFL teachers to implement correctly and successfully thereby. In the light of the preparation and monitoring done by the teachers in class, collaborative learning through $4 / 3 / 2$ activity leads to a positive outcome.

As regards the 4/3/2 activity, a typical communicative language teaching method is warmly welcomed by most EFL students and teachers throughout the observation. There are many positive feedbacks from the participants, for example: this activity is stress free, the class is hilarious and it will be beneficial for the real conversations. Students enjoyed and motivated during the whole period of observation. In summary, this is a good achievement of the study. Dörnyei (2001) stated that the motivational strategies will positively promote the students' motivation and accordingly influence the achievements in language learning. As a result, one role for the EFL teachers is to use different motivational strategies to motivate their learners to participate in different communicative tasks. On the other hand, there are many advantages of adopting the $4 / 3 / 2$ activity in this situation. For instance, the total duration is 18 minutes, which occupies nearly one third of a one-hour lesson. The time is very efficient since an 18 minutes session covers speaking practice for all students. At the same time, the motivation increases in learning responded the participation rate was high and the learning in class brought the language use repetitively outside the class in real life.

The importance of this study is to find out that the teacher's willingness of implementing the speaking fluency and students' preference of it, which is perfectly interdependent. The results in table 5 revealed four sets of test data separately: 1) the male teachers and male students, 2) the male teachers and female students, 3) the female teachers and male students, and 4) the female teachers and female students. More specifically, the male students' preference and female teachers' willingness is not very strong if at the 5\% Sig. level on the contrary, thus the interdependence will be in a weak situation. However, on a whole they were proved that this relationship does not affect by the gender. This is a supplement for the researcher's previous study that there is strong relationship between the teachers and female students with a small 
sample. This study had chosen an equal demography in gender and randomly selected the students and teachers from several high schools. This should give a more reliable and valid outcome. The finding based on a quantitative research will enhance the success of promoting the speaking fluency since teaching and learning share a common goal in the classroom.

Another issue examined was the choices of speaking topics in the 4/3/2 activity. This study provided an opportunity for the participants to choose the topic they would like to practice that is a learner-centered strategy. The teacher should offer autonomy to their students as far as possible. This is also a way to motivate the students. Brown (2007) stated motivation is yet an affective variable to be considered in the language teaching and learning. Ur (1996) argued speaking is the most important skill in learning a foreign language. Such a large demand of speaking skill creates such opportunity to improve speaking fluency. As a consequence, the attention should be paid on meaning-focused output and fluency development strands for the communicative competence. Concerning with the choice of speaking topic, the EFL students would like to choose the topics that will be frequently appeared in the daily life. The more practiced in class, the more will be beneficial for the real conversations. However, the role for the teachers is gradually changed from a reader to a moderator since they need to manage the class and provide assistance rather than teaching grammar rules. Thus, to provide feedback at an appropriate time in communicative language teaching is an issue that needs more research and attention.

The next issue is about the overall achievement after this observation. Table 6 delivered a message that the implementation of the 4/3/2 activity increased the speaking fluency overall. The major achievements are the linguistics knowledge including grammar and vocabulary is expanding and becomes more accurate. The students are able to present structured sentences in logical sequences and the expression is coherent with less pauses. The articulation is faster than before and speaking is more fluent. In addition, they can use conversational strategies in comprehension to maintain the communication more effectively. Student provided feedback in the interview that they are more confident when speaking outside the class. These are also tested by the examiners through testing the participants' relevant speaking competence before the observation as well as afterwards. It is clear that such achievements are dramatically and the overall speaking proficiency is feasibly increased. So speaking competence is a successful trainable skill of this implementation. Nation (2007) stated fluency, accuracy and complexity are most likely to be interdependent. The researcher suggests the teachers could arrange a post writing task to write down the content that used in the 4/3/2 activity. Repetition through writing is at a fourth time, students will not find writing is too difficult.

Finally, the implication of doing this research consists of patience, confidence and motivation in a long period of time. These factors need to be aware of in order to explore an authentic achievement in speaking fluency development. To recall the restriction of the English Only policy, L1 is encouraged to be used when the teachers provide instructions and feedback. Students are convinced to speaking English during the 4/3/2 activity. Furthermore, the teachers should prepare the topic and content, help the students to learn the vocabulary and language items, organize the activity under the required conditions and set up learning goals. The mission for implementing this task is filling the gap between knowing and doing. 


\section{Pedagogical Implication}

There are some further reflections based on the discussion above. The EFL teachers need to create the opportunities for their learners to develop fluency and speaking the target language through real communication at a maximum rate. Students should get used to the collaborative learning environment as learning is not only from their teachers in communicative language teaching, but also from their classmates and the other techniques and facilities. There are plenty of language learning theories, frameworks, methods and approaches, but principle is always a foundation. The researcher suggests that the development of speaking fluency can be followed this guide, that are some advices and tips summarized as the SMART principle based on the findings and discussions and the features of the 4/3/2 activity.

a) Speed: the development of speaking fluency practices the articulation speed, therefore do not hesitate to learn new language items and contents and try to be familiar with the target language and content self-push to articulate fast and try to reduce the pause time. Wood (2001) summarized the speech rate is a key performance indicator of measuring fluency as speech rate shows the overall fluency of speaking.

b) Meaning: the speaking fluency development is meaning-focused learning, which does not mean to neglect form-focused instructions. Learning a language is for the communicative use in life, speaking is the process and convey of the message delivered. Hence, do not be embarrassed when audience points out errors and try to be stress free and be confident when speaking and articulating.

c) Accurate: Fluency improvement also brings accuracy, complexity and control of content (Nation, 1989) through communicative language teaching. That means form and accuracy is internal related, however the retrieval strategy is to use what you have learnt and known, to practice and practice the accurate language items and contents. One old saying said practice makes perfect.

d) Retrieval: fluency is an aim in teaching and a criterion in assessment. It is not good to practice speaking fluency when learners not fully get ready for it. Rossiter et al. (2010) maintained that rehearsal and repetition with consciousness-raising for enhancing oral fluency. Teachers should try to do some rehearsal activities with different audios, or adapt the $4 / 3 / 2$ activity into $5 / 4 / 3$ or $3 / 2 / 1$ that could be a choice due to long or short topics, or adapt the $4 / 3 / 2$ activity into $5 / 3 / 1$ by the different circumstances. No matter how to change the format of the 4/3/2 activity, the concept of relevance should be kept in mind, to avoid using irrelevant words and use relevant words and expressions when practice speaking fluency, this is supplement to de Long and Perfetti’s (2011) finding.

e) Time: learning a language takes time, especially learning a foreign or second language which requires patience, effort and time. Never give up, because learning from mistakes. However, there is no restriction of time and location with the development of modern technologies, for instance, computer assistant language learning with internet media and facilities. Richards (2008) pointed out that technology has shift language learning from teacher-centered to diversified learner-autonomy learning. 


\section{Conclusion}

This study investigated how the high school EFL teachers and students treat the competence of speaking fluency, examined the willingness of implementing speaking fluency is strongly related to the students' preference of practicing the speaking competence, and also explored that the speaking fluency is a trainable skill in a long term practice through the observation of implementing the 4/3/2 activity. These findings in observation suggested that communicative language teaching and learning should be in a motivated, stress-free, interesting and practical language learning environment. The relevant feedback from the participants in interview is the treatment for the researcher and teachers to provide strategic implementation in the EFL class, to know the progress in what degrees and to understand the problem more specifically. Interview is encouraged to arrange before, during and after the observation in order to collect valuable information for improving teaching quality and learning motivation. The discussion and reflection of this observation suggested a SMART principle for practicing the speaking fluency in the EFL class. As a matter of fact, this article justified and concluded that speaking fluent is a trainable skill and EFL learning needs patience, effort and time. The pedagogical implication suggested that the speaking fluency practiced in class will be beneficial for the real-life conversation. However, to adapt the 4/3/2 into a 5/3/1 format is not considered and discussed yet, which is a challenge task needs further research and demonstration.

\section{References}

Anderson, J. (1993). Is a communicative approach practical for teaching English in China? Pros and cons. System, 21(4), 471-480. http://dx.doi.org/10.1016/0346-251X(93)90058-O

Anton, M., \& and DiCamilla, F. (1998). Socio-cognitive functions of L1 collaborative interaction in the L2 classroom. The Canadian Modern Language Review, 54, 315-342. http://dx.doi.org/10.3138/cmlr.54.3.314

Auerbach, E.R. (1993). Reexamining English only in the ESL classroom. TESOL Quarterly, 27, 9-32. http://dx.doi.org/10.2307/3586949

Arevart, S., \& Nation, I.S.P. (1991). Fluency improvement in a second language. RELC Journal, 22(1), 84-94. http://dx.doi.org/10.1177/003368829102200106

Bouangeune, S. (2009). Using L1 in teaching vocabulary to low English proficiency level students: A case study at the University of Laos. English Language Teaching, 2(3), 186-193.

Brown, H. D. (2002). English language teaching in the "post-method" era: Toward better diagnosis, treatment and assessment. In J. C. Richards and W. A. Renandya (Eds.), Methodology in language teaching: An anthology of current practice (pp. 9-18). Cambridge: Cambridge University Press. http://dx.doi.org/10.1017/CBO9780511667190.003

Brown, H.D. (2007). Principles of language learning and teaching (5th ed.). New York: Pearson Longman.

Brown, G., \& Yule, G. (1983). Discourse analysis. Cambridge: Cambridge University Press. http://dx.doi.org/10.1017/CBO9780511805226 
Brumfit, C. (1984). Communicative methodology in language teaching: The roles of fluency and accuracy. Cambridge: Cambridge University Press.

Canale, M., \& Swain, M. (1980). Theoretical bases of communicative approaches to second language teaching and testing. Applied Linguistics, 1, 1-47.

$\mathrm{http}: / / \mathrm{dx}$. doi.org/10.1093/applin/I.1.1

Canale, M. (1983). From communicative competence to communicative language pedagogy. In J. C. Richards \& R. W. Schmidt (Eds.), Language and communication (pp. 2-27). London: Longman.

Candlin, C. (1988). 'Methods in English language teaching' in international English language teaching. Prentice Hall: New York.

Chomsky, N. (1965). Aspects of the theory of syntax. Cambridge, Mass: MIT Press.

Clarke, M., \& Silberstein, S. (1997). Toward a realization of psycholinguistic principles in the ESL reading class. Language Learning, 27(1), 48-65.

de Jong, N., \& Perfetti, C. A. (2011). Fluency training in the ESL classroom: An experimental study of fluency development and proceduralization. Language Learning, 61(2), 533-568. http://dx.doi.org/10.1111/j.1467-9922.2010.00620.x

Deepti, G. (2004). CLT in India: context and methodology come together. ELT journal, 58(3), 266-269. http://dx.doi.org/10.1093/elt/58.3.266

Dörnyei, Z. (2001). Motivational strategies in the language classroom. Cambridge: Cambridge University Press. http://dx.doi.org/10.1017/CBO9780511667343

Ellis, R. (1984). Classroom second language development. Oxford: Pergamon.

Ellis, R. (2008). The study of second language acquisition. Oxford: Oxford University Press.

Ellis, G., \& Sinclair, B. (1989). Learning to learn English: a course in learner training. Cambridge: Cambridge University Press.

Fillmore, C. J. (1979). On fluency. In D. Kempler \& W. S. Y. Wang (Eds.), Individual differences in language ability and language behavior (pp.85-102). New York: Academic Press.

Fotos, S. (2001). Cognitive approaches to grammar instruction. In M. Celce-Murcia (Eds.), Teaching English as a second or foreign language (3rd ed., pp. 267-283). Boston: Heinle and Heinle.

Guo, J. (2004). Communicative language teaching in EFL settings: A long way to go. Retrieved from http://www.celea.org.cn/pastversion/lw/pdf/guojie.pdf (Jan 13, 2014）

Habermas, J. (1970). Towards a theory of communicative competence. Inquiry, 13, 360-375. http://dx.doi.org/10.1080/00201747008601597

Harvey, P. (1985). A lesson to be learned: Chinese approaches to language learning. ELT Journal, 39(3), 183-186. http://dx.doi.org/10.1093/elt/39.3.183 
Hird, B. (1995). Teaching English communicatively in China - Educating teachers is not enough. Australian Journal of Teacher Education, 20(2), 1-4.

http://dx.doi.org/10.14221/ajte.1995v20n2.1

Hedge, T. (2000). Teaching and learning in the language classroom. Oxford: Oxford University Press.

Hymes, D. H. (1971). Competence and performance in linguistic theory. In R. Huxley \& E. Ingram (Eds.), Language acquisition: Models and methods (pp.3-28). London: Academic Press.

Hymes, D. H. (1972). On communicative competence. In C. J. Brumfit \& K. Johnson (Eds.), The communicative approach to language teaching (2nd ed., pp.5-27). Oxford: Oxford University Press.

Jin, Y. (2006). The improvement of the test validity and its backwash effects. Foreign Language World, 6, 65-73.

Krashen, S. (1988). The input hypothesis: issues and implications. London: Longman.

Kormos, J., \& Dénes, M (2004). Exploring measures and perceptions of fluency in the speech of second language learners. System, 32(2), 145-164.

http://dx.doi.org/10.1016/j.system.2004.01.001

Larsen-Freeman, D. (2000). Techniques and principles in language teaching. Oxford: Oxford University Press.

Li, D. (1998). It's always more difficult than you plan and imagine: teachers perceived difficulties in introducing the communicative approach in South Korea. TESOL Quarterly, 32(4), 677-703. http://dx.doi.org/10.2307/3588000

Liao, X. (2004). The need for communicative language teaching in China. ELT journal, 58(3), 270-273. http://dx.doi.org/10.1093/elt/58.3.270

Maurice, K. (1983). The fluency workshop. TESOL Newsletter, 17(4), 29.

Nation, I.S.P. (1989). Improving speaking fluency. System, 17(3), 377-384.

http://dx.doi.org/10.1016/0346-251X(89)90010-9

Nation, I.S.P. (1991). Fluency and learning. The English Teacher, 20, 1-8.

Nation, I.S.P. (1997a). Developing fluency in language use. KIFL Academic Journal, 6, $30-35$.

Nation, I.S.P. (1997b). L1 and L2 use in the classroom: a systematic approach. TESL Reporter, $30(2), 19-27$.

Nation, I.S.P. (2007). The four strands. Innovation in Language Learning and Teaching, 1(1), 1-12. http://dx.doi.org/10.2167/illt039.0

Oxford, R. (1997). Cooperative learning, collaborative learning, and interaction: Three 
communicative strands in the language classroom. The Modern Language Journal, 81(4), 443-456. http://dx.doi.org/10.1111/j.1540-4781.1997.tb05510.x

Penner, J. (1995). Change and conflict: Introduction of the communicative approach in China. TESL Canada Journal, 12(2), 1-17.

Prabhu, N.S. (1987). Second language pedagogy. Oxford: Oxford University Press.

Richards, J.C. (2006). Communicative language teaching today. Cambridge: Cambridge University Press.

Richards, J.C. (2008). Growing up with TESOL. English Teaching Forum, 46(1), 2-11.

Richards, J. C., \& Rogers, T. S. (1986). Approaches and methods in language teaching: A description and analysis. Cambridge: Cambridge University Press.

Richards, J.C., \& Rogers, T.S. (2002). Approaches and methods in language teaching. Cambridge: Cambridge University Press. http://dx.doi.org/10.1017/CBO9780511667190

Richards, J. C., Platt, J., \& Weber, H. (1985). Longman dictionary of applied linguistics. London: Longman.

Rossiter, M.J., Derwing, T.M., Manimtim, L.G., \& Thomson, R.I. (2010). Oral Fluency: The neglected component in the communicative language classroom. Canadian Modern Language Review, 66(4), 583-606. http://dx.doi.org/10.3138/cmlr.66.4.583

Savignon, S.J. (1972). Communicative competence: An experiment in foreign language teaching. Philadelphia, PA: Center for Curriculum Development.

Sampson, G.P. (1984). Exporting language teaching methods from Canada to China. TESL Canada Journal, 1(1), 19-32.

Stern, H. H. (1992). Issues and options in language teaching. Oxford: Oxford University Press.

Tang, J. (2002). Using L1 in the English classroom. English Teaching Forum, 40(1), 36-43.

Turnbull, M. (2001). There is a role for the L1 in second and foreign language teaching, but.... Canadian Modern Language Review, 57, 531-540. http://dx.doi.org/10.3138/cmlr.57.4.531

Ur, P. (1996). A course in language teaching: Practice \& theory. Cambridge: Cambridge University Press.

Widdowson, H.G. (1978). Teaching language as communication. Oxford: Oxford University Press.

Wood, D. (2001). In search of fluency: What is it and how can we teach it? Canadian Modern Language Review, 57(4), 573-589. http://dx.doi.org/10.3138/cmlr.57.4.573

$\mathrm{Wu}, \mathrm{W}$. (2008). Misunderstandings of Communicative Language Teaching. English language teaching, 1(1), 50-53. 


\section{Macrothink}

International Journal of English Language Education

ISSN $2325-0887$ 2014, Vol. 2, No. 1

Yu, L. (2001). Communicative language teaching in China: Progress and resistance. TESOL Quarterly, 35(1), 194-198. http://dx.doi.org/10.2307/3587868 


\section{Appendix}

Questionnaire for the Implementation of the 4/3/2 Activity

Dear Participants,

This questionnaire is designed for the participants involved in the $4 / 3 / 2$ activity to improve their speaking fluency through the communicative language teaching. The results and findings in this survey will be used for research purpose only.

Thank you very much for your time to answer the following questions and your participation and effort is highly respected.

Question 1: Please tick to box for your gender and role

\begin{tabular}{r|l|l}
\hline Gender: & $\square$ Male & $\square$ Female \\
\hline Role: & $\square$ EFL Teacher & $\square$ EFL Student \\
\hline
\end{tabular}

Please select the best option from your point of view

Question 2:

Do you think that speaking fluency is important when processing speaking with others for communicative purpose?

Very important

$\square$ Important

Important to some degrees

Not sure, uncertain

Not important at all

Question 3:

Is the competence of speaking fluency necessary to develop when practicing the speaking skill through the CLT teaching?

$\square$ Essentially necessary

$\square$ Necessary

Necessary to some extend

Not sure, uncertain

Not necessary at all

Please rate from 1 to 5 to comment on your opinion for the following statements (1-Strongly disagree, 2-Disagree, 3-Uncertain, 4-Agree and 5-Strongly agree) Question 4:

The practice and development of speaking fluency in your EFL class is not enough to maintain the communicative language usage? $\square 1 \quad \square 2 \quad \square 3 \quad \square 4 \quad \square 5$

Question 5:

You are willing to improve the communicative competence of speaking fluency through the communicative language teaching in EFL class? $\square 1 \quad \square 2 \quad \square 3 \quad \square 4 \quad \square 5$ 
Question 6:

Please select the following topics that you would like to practice the speaking fluency through the $4 / 3 / 2$ activities.

\begin{tabular}{|l|l|l|}
\hline \multicolumn{1}{|c|}{ Topic } & \multicolumn{2}{c|}{ Preference } \\
\hline & Male & Female \\
\hline To do a self-introduction & & \\
\hline Introduce and describe your family & & \\
\hline Share your school life to your classmates & & \\
\hline Weather in your city & & \\
\hline Transportation development & & \\
\hline Sports and competition & & \\
\hline Entertainment and hobby & & \\
\hline Discuss shopping experiences & & \\
\hline How to find a job & & \\
\hline Ask the way and giving direction & & \\
\hline Talk about the daily food & & \\
\hline Explore how to keep healthy & & \\
\hline Dreams in your life & & \\
\hline Travel to a place & & \\
\hline Your future plan and plan your future & & \\
\hline Introduce one of your best friends & & \\
\hline
\end{tabular}

Question 7: This question is for the evaluators only!

Please evaluate the students' proficiency of the speaking competence pre and post this observation, rate from 1 to 5 with the following criteria.

$\bigcirc 1$ (very poor competence)

$\bigcirc 2$ (poor competence)

3 (basic competence)

4 (good competence)

5 (outstanding competence)

\begin{tabular}{|c|c|c|}
\hline Criteria & Before & After \\
\hline $\begin{array}{l}\text { 1. Linguistics knowledge i.e. grammar, vocabulary and etc, is } \\
\text { expand and becomes more accurate }\end{array}$ & & \\
\hline 2. Pragmatic and logic is in structured sentences and sequences & & \\
\hline 3. Expression is coherent with less pause while speaking & & \\
\hline 4. Speaking is fluent and the word articulation is fast & & \\
\hline $\begin{array}{l}\text { 5. Be able to use conversational strategies in comprehension to } \\
\text { maintain communication effectively }\end{array}$ & & \\
\hline 6. Be confident in speaking with others & & \\
\hline Average & & \\
\hline
\end{tabular}




\section{Copyright Disclaimer}

Copyright reserved by the author(s).

This article is an open-access article distributed under the terms and conditions of the Creative Commons Attribution license (http://creativecommons.org/licenses/by/3.0/). 